\title{
The Effect of Information Technology in Creative Marketing "Case Study- Jordan Tourism Board"
}

\author{
Ibrahim Kahlil Bazazo \\ Travel and Tourism Management, Faculty of Tourism and Hospitality \\ The University of Jordan \\ E-mail: i.bazazo@ju.edu.jo
}

Ehab Abdul Raheem Alshatnawi

Travel and Tourism Management, Faculty of Tourism and Hospitality

The University of Jordan $\backslash$ Aqaba

E-mail: e.shatnawi@ju.edu.jo

Ranea Mohammad Qaddhat

Travel and Tourism Management, Faculty of Tourism and Hospitality

The University of Jordan $\backslash$ Aqaba

E-mail: r.qaddahat@ju.edu.jo

Ihab Ahmad Alomari

Department of tourism and Hotel science, Al- Balqa' Applied University

E-mail: white.stroke@yahoo.com

Received: April 24, 2016

Accepted: May 17, 2016 Published: July 1, 2016

doi:10.5296/jmr.v8i3.9315

URL: http://dx.doi.org/10.5296/jmr.v8i3.9315 


\begin{abstract}
This study aims to assess the effect of information technology on the creative marketing at Jordan Tourism Board in order to provide recommendations and suggestions needed to improve the capacity of Jordan Tourism Board to reach a wider tourism markets worldwide, and market Jordanian tourism products in a high effectiveness through using new technological means. To achieve the study objective, a self-administrated questionnaire developed and then distributed to the employees of Jordan Tourism board to know their perspective toward the effect of information technology on the creative marketing.

The results revealed that there is a significant relation between sophisticated information technology and the ability to reach tourism markets, as well as a significant relation between developed technological software and creative marketing. They also showed a significant relation between trained and qualified human resources and creative marketing. Finally, this study emphases on the importance of having qualified and trained human resources and advanced technological means and software so as to increase the Jordanian tourism market share and reach new markets.
\end{abstract}

Keywords: Information Technology, Creative Marketing, Jordan Tourism Board 


\section{Introduction}

Tourism sector has been witnessing many changes and developments on the international and regional levels since the onset of the present century, so it is viewed as the twenty-first industry beside the communication and information technology sector. The organizations involved in marketing tourist products are unable to live in isolation from those developments, so it is important to grasp the modern developments in tourism marketing to step into the global markets through acquiring the technical means that can deliver the touristic product to all types of tourists on the international level (jawabreh,2014; Mohammad).

Creative marketing in tourism domain depends on the capability to generate new applicable ideas that can contribute in the development of the Jordanian tourist industry.

Subsequently, utilizing the information technology will probably play a significant role in highlighting the natural, demographic and civilizational constituents in Jordan. This relies on the qualified and trained human resources in the tourism board through providing all the necessary means, instruments and competences to achieve creative marketing (jawabreh,2012).

The world is now witnessing a revolution in communications and information technology which leads to the rapid development in various spheres. Consequently, with this revolution the world has become as a small village where knowledge and information, Since the Internet is one of the most modern methods used to exchange and spread information and knowledge with a lowest cost, and at the present time it is hardly to find an institution, whether private or public, lacks of a section that deals with and manages the information technology or a website in order to present information and services which are provided by each organization for its reviewers and its interested people, and there are websites for all ministries, universities and institutions in the Kingdom through which the browser can get the information that he wants (ALsarayreh and Others, 2011).

\section{Problem of the Study}

The world is currently witnessing a technological revolution in all general walks of life, and despite the technological development in all ends of tourism industry, the effect of information technology on the creative tourist marketing, whether on the level of working labor in tourist institutions or on the level of tourism activating boards, is still not clear-cut because there is no clear visualization at the institutions in charge of tourist marketing to the importance of owning modern techniques to realize creative marketing to the touristic product. Therefore, the study's questions revolved around the following:

Dose the Jordan tourism board care for achieving a state of creative tourist marketing?

Do those in charge of tourist marketing at the Jordan tourism board recognize the importance of possessing the creative marketing skills?

Is there a real tangible effect for using information technology in creative marketing at Jordan tourism board? 


\section{Significance of the Study}

The significance of the study emerges from the following:

1- The tourism sector in Jordan is considered as an important source of national income as it constitutes $15 \%$ of the total national income.

2- Creative marketing is an essential requirement to push the wheel of development in the Jordanian tourist sector and to increase the international market allotment by means of depending on technological tools.

3- The importance of tourism activating board to possess advanced technological software which contributes in improving the quality of the produced tourist services.

4- This study forms the starting point for a researching trend that concentrates on the studies related to creative marketing in the tourist sector.

\section{Objectives of the Study}

This study aims at identifying the actuality of using information technology in the Jordan tourism board and its impact on creative marketing through realizing the following objectives:

1- Recognizing the most important technological software and their levels and fields of using them in marketing the Jordanian tourist product.

2- Determining the level of creative marketing achieved by the tourism activating board.

3- Investigating the nature of the relationship between information technology and creative marketing.

4- Providing the tourist decision maker with the most important possible means through adopting the creative marketing concept to realize a bigger market share on the international level. 


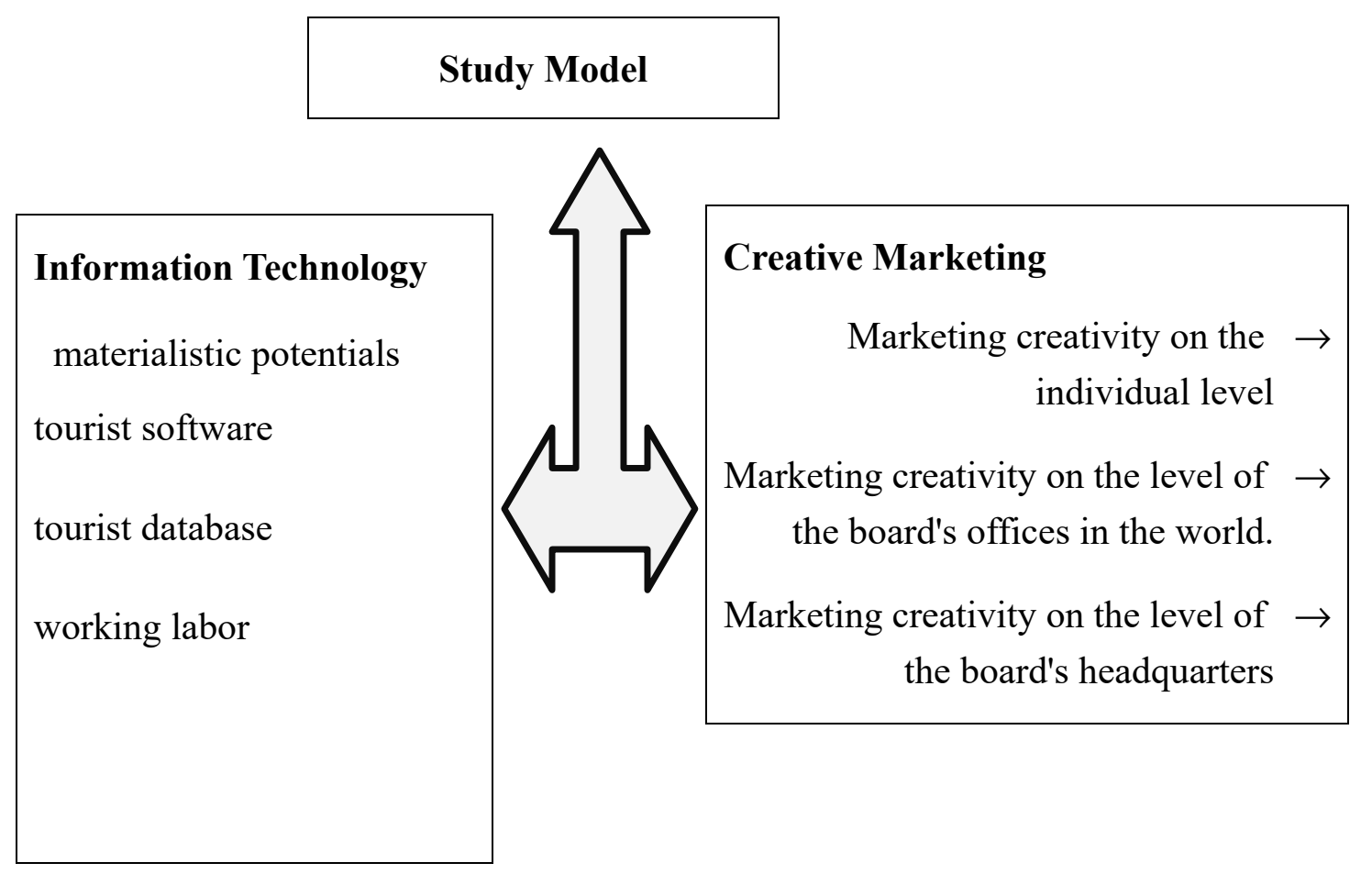

Figure 1. Study Model

\section{The Study Population and Sample}

The study population consists of all the employees and managers of the Jordan tourist board whereupon (100) questionnaires were distributed from which (75) questionnaires representing (88\%) were retrieved. All the collected questionnaires were fit for statistical analysis. This means that the actual number of questionnaires that were subjected to statistical analysis was (75) questionnaires.

\section{The Study Methodology}

The methodology used by the researcher depended on the study design, the study population and sample, method of preparation, validity and reliability indicators, in addition to data collection and analysis and the statistical treatments used in analysis.

The designing process related to scientific studies depends on the nature of the problem under study and the objectives expected to be achieved when treatment is accomplished.

The researcher followed the descriptive analytical approach and the field study method being the most corresponding to the current study. The researcher also touched on the available references and resources to prepare the theoretical framework of the study. As for the field side, the researcher used the questionnaire as a basic instrument to collect data and analyze it statistically reaching at analyzing the study hypotheses. The questionnaire was built up by reviewing the literature related to the science of tourist management, referring to previous studies and researches and through holding discussions with a large number of academics and experts specialized in tourism, in addition to the researcher's experience in this field, and the 
tool was subjected to the validity and reliability tests.

Likert five point scale was used for the closed questions (from 5 to 1) expressing the degree of the respondent's approval where the score (5) was given to 'strongly agree', (4) to 'agree', (3) to 'neutral', (2) to 'disagree' and (1) to 'totally disagree'. By redistributing the scale according to the length of category through applying the equation of category length: (maximum limit - minimum limit) divided by the number of categories $(5-1) / 5=4 / 5=0.8$. The following table shows the scale's scores according to the length of category of the respondent's approval degree and assessment degree, the technology usage level and its impact on the creative marketing in tourist domain.

\subsection{Hypotheses of the Study}

To achieve the objectives of the study, and to measure the relationship between information technology and creative marketing in Jordan tourism board, a set of hypotheses were adopted as follows:

The First Main Hypothesis: There is a moral correlative relationship between information technology and creative marketing.

The Second Main Hypothesis: There is a moral influential relationship between information technology and creative marketing and the following points emerged from this hypothesis:

1- There is a statistically significant relationship between the materialistic potentials and creative marketing.

2- There is a statistically significant relationship between the tourist technological software and creative marketing.

3- There is a statistically significant relationship between the working labor in the tourism activating board and creative marketing.

4- There is a statistically significant relationship between the tourist database related to tourist attraction potentials and tourist facilities and creative marketing. 


\section{Macrothink}

Table 1 . The scale's scores according to the length of the variables category

\begin{tabular}{|l|l|l|l|}
\hline $\begin{array}{l}\text { Value } \\
\text { in } \\
\text { scale }\end{array}$ & Length of category & Degree of approval & Performance assessment \\
\hline 1 & $1-1.6$ & Totally disagree & Very low performance level \\
\hline 2 & $1.41-2.3$ & Disagree & low performance level \\
\hline 3 & $2.51-3.5$ & Neutral & medium performance level \\
\hline 4 & $3.91-4.5$ & Agree & High performance level \\
\hline 5 & $4.11-5$ & Strongly agree & Very high performance level \\
\hline
\end{tabular}

As for the open questions, the researcher depended on the method of frequencies in localizing the responses of the sub-categories of the study's population.

\section{Validity and Reliability Tests}

Prior to adopting the study's tool - the questionnaire - by the researcher, in addition to the incorporated questions which were directed to different sides, the quality of the scale had to be tested through what is called testes of validity and reliability. The valid tool is the one that measures what it is designed to measure. What is intended by the validity of the tool is the validity of the collected results using that tool. It is possible to distinguish between external validity and internal validity.

The external validity of the tool is connected to the extent of the results validity by using that tool for generalization; it is also connected with the accuracy in applying the tool, the accuracy in designing the study, the accuracy of taking measurements or collecting data and producing a main interpretation to the correlative relationships.

In order to measure the reliability coefficient, chronbach's alpha coefficient was used. The test was made for each of the study's variables separately. The statistical rule for this test states that the acceptable rate is $60 \%$ or more (Sekearan). The outcomes of the tests came as follows: 
Table 2. The results of Chronbach's Alpha Test for the Study's Questionnaire

\begin{tabular}{|l|l|c|l|}
\hline No. & Main variables & No. of sub-variables & $\begin{array}{l}\text { Coefficient } \\
\text { value }\end{array}$ \\
\hline 1 & $\begin{array}{l}\text { The materialistic potentials and their effect on } \\
\text { creative marketing }\end{array}$ & 0.845 \\
\hline 2 & $\begin{array}{l}\text { Tourist software and its effect on creative } \\
\text { marketing }\end{array}$ & 3 & 0.847 \\
\hline 3 & $\begin{array}{l}\text { Tourist databases and their effect on creative } \\
\text { marketing }\end{array}$ & 4 & 0.844 \\
\hline
\end{tabular}

Table (2) shows that the coefficient value of chronbach's Alpha test for the first part of the questionnaire directed to the materialistic potentials and their effect on creative marketing and contained $15 \mathrm{sub}$ - clauses was high and statistically acceptable with the value of (0.734). The value of the second section of the questionnaire which contained $17 \mathrm{sub}$ - clauses related to tourist software and its effect on creative marketing reached at (0.736) and this is similarly acceptable statistically. As for the third section of the questionnaire which contained six sub clauses about the tourist databases and their effect on creative marketing, the coefficient value of chronbach's Alpha test was (0.733) which is also statistically acceptable. This generally means that the questionnaire enjoyed a high level of validity and reliability.

\section{Previous Studies}

A number of studies handled the importance of electronic software and information technology in creative marketing in general, but very few of them dealt with creative marketing in tourism.

The most prominent studies is the study of (Asters:2012) under the title, "The Role of Information Technology in making the Touristic Decision". This study aimed at identifying the role of information technology in improving the process of taking tourist decisions. For that purpose, the researcher conducted a comprehensive survey for all the workers at the New Zealand Ministry of Tourism who count (300) employees.

The study revealed that the use of information technology improves the process of decision making. In addition, there are no differences in the trends of the employees at the New Zealand Ministry of Tourism concerning the role of information technology in the effectiveness of taking tourist decisions due to gender, experience and academic qualification, while there are differences due to age, position and training courses.

The study of (Ragertu: 2012) under the title "comparison between the tourist institutions of the public and private sectors in India in possessing technological software and their effect in creative tourist marketing". The study showed the lack of interest of the two sectors with any 
of the stated aspects except for the care of the private sector's institutions for the digital technology related to marketing tourist products without connecting it to the concept of creative marketing.

The study of (Sarbem: 2011) with the title, "The economic effect of information technology in the tourist sector". The study investigates the connection between using information technology and the marketing ability of the tourist sector and moving into new marketing. The researcher found that the pioneering tourist institutions use technological software to achieve higher levels of investment returns in the tourist sector. The study indicated that the tourist institutions that use information technology more than other institutions obtain high organizational dimension and higher competitive capability.

The study of (Cardsa: 2011) under the title, "The effect of using information technology on creative marketing: applied study on tourism offices in Greece". The researcher pointed out the reality of using information technology in tourism offices in Greece and its impact on creative marketing to recognize the level of creative marketing in travel and tourism agencies. The researcher referred to the existence of a positive relationship between information technology and creative marketing, and methods of applying the effective creativity at tourist offices, in addition to the presence of a positive relationship between information technology and the competitive advantage of tourist offices in Greece.

This study comes as a complement to what was initiated by researchers in this domain through concentrating on the role of information technology in realizing the concept of creative marketing in reference to Jordan Tourism Board as a Study Case.

\section{Analyzing Results and Testing Hypotheses}

\subsection{Materialistic Potentials:}

The statistical results that rely on the replicative distribution of the materialistic potentials' clauses point out that the highest rate of the employees of tourism activating board believe that the tourism board, as an institution, cares for possessing the best materialistic components available on the international tourism level, as the rate reached at $(39.0 \%)$. In the same direction, we notice that $(12.4 \%)$ of the sample's members rather agree on this variable while (42.6\%) expressed their disagreement on their company's attention to the materialistic components and their relevant aspects. Those responses came with an arithmetic mean of (12.18) and a standard deviation of (.761). 
Table 3. Replicative Distributions, Arithmetic Mean and Standard Deviation of the Materialistic Potentials Variable

\begin{tabular}{|c|c|c|c|c|c|c|c|c|c|c|c|c|}
\hline \multirow[t]{3}{*}{$\mathrm{S} / \mathrm{N}$} & \multicolumn{10}{|c|}{ Response } & \multirow{3}{*}{$\begin{array}{l}\text { Arithmetic } \\
\text { mean }\end{array}$} & \multirow{3}{*}{$\begin{array}{l}\text { Standard } \\
\text { deviation }\end{array}$} \\
\hline & \multicolumn{2}{|c|}{$\begin{array}{l}\text { Strongly } \\
\text { agree }\end{array}$} & \multicolumn{2}{|c|}{ agree } & \multicolumn{2}{|c|}{$\begin{array}{l}\text { Rather } \\
\text { agree }\end{array}$} & \multicolumn{2}{|c|}{ disagree } & \multicolumn{2}{|c|}{$\begin{array}{l}\text { Strongl } \\
\mathrm{y} \\
\text { disagree }\end{array}$} & & \\
\hline & $\mathrm{T}$ & $\%$ & $\mathrm{~T}$ & $\%$ & $\mathrm{~T}$ & $\%$ & $\mathrm{~T}$ & $\%$ & $\mathrm{~T}$ & $\%$ & & \\
\hline $\mathrm{X} 1$ & 11 & 14,8 & 23 & 41,0 & 1 & 3,4 & 9 & 31,7 & 2 & 1 & 4,0636 & 1,0460 \\
\hline $\mathrm{X} 2$ & 1 & 1 & 11 & 32,9 & 8 & 22,5 & 21 & 36,8 & 3 & 7,7 & 3,4770 &, 6593 \\
\hline $\mathrm{X} 3$ & 5 & 20,9 & 11 & 12,9 & 5 & 15,0 & 19 & 35,8 & 1 & 5,3 & 2,4683 & 1,1481 \\
\hline $\mathrm{X} 4$ & 1 & 1,2 & 13 & 34,3 & 9 & 31,7 & 19 & 34,7 & 2 & 1,1 & 2,4321 &, 8300 \\
\hline indicator & & & & & & & & & & & 2,3631 & 0,4609 \\
\hline
\end{tabular}

\subsection{Electronic Tourist Software:}

The results of table (4) point out that the responses of (66.4\%) of the sample's members agree on the attention of the tourist activating board with the electronic tourist software and the use of the most modern software, while (13.9\%) of the subjects rather agree. The arithmetic mean pointed to (4.120) with a standard deviation of (.431). 
Table 4. Replicative Distributions, Arithmetic Means and Standard Deviations of the Tourist Software Variable

\begin{tabular}{|c|c|c|c|c|c|c|c|c|c|c|c|c|}
\hline \multirow[t]{4}{*}{$\mathrm{S} / \mathrm{N}$} & \multicolumn{10}{|c|}{ Response } & $\begin{array}{l}\text { Arithmetic } \\
\text { mean }\end{array}$ & $\begin{array}{l}\text { Standard } \\
\text { deviation }\end{array}$ \\
\hline & \multicolumn{10}{|c|}{2} & & \\
\hline & \multicolumn{2}{|c|}{$\begin{array}{l}\text { Strongly } \\
\text { agree }\end{array}$} & \multicolumn{2}{|c|}{ agree } & \multicolumn{2}{|c|}{$\begin{array}{l}\text { Rather } \\
\text { agree }\end{array}$} & \multicolumn{2}{|c|}{ disagree } & \multicolumn{2}{|c|}{$\begin{array}{l}\text { Strongly } \\
\text { disagree }\end{array}$} & & \\
\hline & $\mathrm{T}$ & $\%$ & $\mathrm{~T}$ & $\%$ & $\mathrm{~T}$ & $\%$ & $\mathrm{~T}$ & $\%$ & $\mathrm{~T}$ & $\%$ & & \\
\hline $\mathrm{X} 5$ & 12 & 34,2 & 22 & 44,2 & 1 & 7,1 & 6 & 13,1 & 1 & 1 & 2,9834 &, 56783 \\
\hline X6 & 9 & 32,6 & 12 & 45,4 & 3 & 6,6 & 7 & 12,0 & 2 & 1 & 2,4325 &, 75463 \\
\hline $\mathrm{X} 7$ & 11 & 33,1 & 19 & 39,4 & 7 & 17,5 & 3 & 7,3 & 1 & 1 & 2,1568 & , 96543 \\
\hline $\mathrm{X} 8$ & 5 & 56,0 & 23 & 49,1 & 6 & 15,3 & 5 & 11,0 & 2 & 3,3 & 2,3453 & 1,3245 \\
\hline indicator & & & & & & & & & & & 2,3421 & 0,2764 \\
\hline
\end{tabular}

\subsection{Working Labor}

The results of table (5) indicate that (55.5\%) of the sample's members agree that the tourism activating board has a clear vision to train and develop the working labor, through which it seeks to develop, diversify and improve their skill and capability to realize a suitable work environment. We also find that $(15.3 \%)$ of the sample's members rather agree on that, while we notice that $(14.3 \%)$ of the subjects do not agree on the importance of this variable. This was demonstrated by the arithmetic means $(5,6570)$ and $(4,981)$ with standards deviations of (.463) and (1.562) respectively. 
Table 5. Replicative Distributions, Arithmetic Means and Standard Deviations of the Working Labor Variable

\begin{tabular}{|c|c|c|c|c|c|c|c|c|c|c|c|c|}
\hline \multirow[t]{3}{*}{$\mathrm{S} / \mathrm{N}$} & \multicolumn{10}{|c|}{ Response } & \multirow{3}{*}{$\begin{array}{l}\text { Arithmeti } \\
\text { c mean }\end{array}$} & \multirow{3}{*}{$\begin{array}{l}\text { Standard } \\
\text { deviation }\end{array}$} \\
\hline & \multicolumn{2}{|c|}{$\begin{array}{l}\text { Strongly } \\
\text { agree }\end{array}$} & \multicolumn{2}{|c|}{ agree } & \multicolumn{2}{|c|}{$\begin{array}{l}\text { Rather } \\
\text { agree }\end{array}$} & \multicolumn{2}{|c|}{ disagree } & \multicolumn{2}{|c|}{$\begin{array}{l}\text { Strongly } \\
\text { disagree }\end{array}$} & & \\
\hline & $\mathrm{T}$ & $\%$ & $\mathrm{~T}$ & $\%$ & $\mathrm{~T}$ & $\%$ & $\mathrm{~T}$ & $\%$ & $\mathrm{~T}$ & $\%$ & & \\
\hline X9 & 2 & 4,3 & 19 & 44,6 & 11 & 25,3 & 8 & 14,5 & 2 & 2 & 2,8765 & ,7786 \\
\hline $\mathrm{X} 10$ & 7 & 16,5 & 33 & 76,4 & 4 & 7,5 & 2 & 6,1 & 1 & 1 & 3,3245 &, 3456 \\
\hline $\mathrm{X} 11$ & 3 & 6,5 & 25 & 55,8 & 7 & 11,0 & 3 & 4,7 & 3 & 6,7 & 3,7896 & 1,2356 \\
\hline $\mathrm{X} 12$ & 11 & 32,3 & 6 & 16,3 & 11 & 25,1 & 8 & 15,7 & 3 & 7,6 & 2,3245 & 1,9087 \\
\hline indicator & & & & & & & & & & & 2,4521 & 11278, \\
\hline
\end{tabular}

\subsection{Databases:}

The results of table (6) point out that $(45.3 \%)$ of the sample's members agree that the tourism activating board has databases. We also see that (16.2\%) of the members rather agree on this idea, while $(18.6 \%)$ of the subject members do not agree on the importance of this variable. Those responses were with an arithmetic mean of $(, 4533)$ and a standard deviation of $(, 567)$. 
Table 6. Replicative Distributions, Arithmetic Means and Standard Deviations of the Databases Variable

\begin{tabular}{|c|c|c|c|c|c|c|c|c|c|c|c|c|}
\hline \multirow[t]{3}{*}{$\mathrm{S} / \mathrm{N}$} & \multicolumn{10}{|c|}{ Response } & \multirow{3}{*}{$\begin{array}{l}\text { Arithmetic } \\
\text { mean }\end{array}$} & \multirow{3}{*}{$\begin{array}{l}\text { Standard } \\
\text { deviation }\end{array}$} \\
\hline & \multicolumn{2}{|c|}{$\begin{array}{l}\text { Strongly } \\
\text { agree }\end{array}$} & \multicolumn{2}{|c|}{ agree } & \multicolumn{2}{|c|}{$\begin{array}{l}\text { Rather } \\
\text { agree }\end{array}$} & \multicolumn{2}{|c|}{ disagree } & \multicolumn{2}{|c|}{$\begin{array}{l}\text { Strongly } \\
\text { disagree }\end{array}$} & & \\
\hline & $\mathrm{T}$ & $\%$ & $\mathrm{~T}$ & $\%$ & $\mathrm{~T}$ & $\%$ & $\mathrm{~T}$ & $\%$ & $\mathrm{~T}$ & $\%$ & & \\
\hline X16 & 4 & 9,3 & 22 & 76,8 & 5 & 7,6 & 9 & 43,8 & 2 & 3,2 & 4,6754 & 2,5643 \\
\hline $\mathrm{X} 17$ & 3 & 7,8 & 19 & 65,0 & 8 & 17,5 & 8 & 43,4 & 1 & 1 & 4,3245 & ,2345 \\
\hline $\mathrm{X} 18$ & 4 & 9,6 & 27 & 45,5 & 3 & 7,3 & 4 & 23,7 & 3 & 7,7 & 3,8765 & 2,8798 \\
\hline X19 & 5 & 11,0 & 16 & 34,7 & 13 & 36,5 & 5 & 67,5 & 3 & 5,4 & 4,1765 & 1,1289 \\
\hline indicator & & & & & & & & & & & 3,8324 & 0,9820 \\
\hline
\end{tabular}

\subsection{The Creative Marketing Variables}

Adopting the concept of creative marketing at the tourism activating board:

The results of table (7) showed that $(12,7 \%)$ agree that the tourism activating board pays great attention to enable the workers to possess the technological means that help in creative marketing whereas the study showed that $(22,1 \%)$ rather agree with it. However, the percentage of the members who do not agree was $(45,2 \%)$ with an arithmetic mean of $(2,786)$ and a standard deviation of $(, 789)$. 


\section{Macrothink}

Journal of Management Research

ISSN 1941-899X

2016, Vol. 8, No. 3

Table 7. Replicative Distributions, Arithmetic Means and Standard Deviations of the Creative Marketing Variable

\begin{tabular}{|c|c|c|c|c|c|c|c|c|c|c|c|c|}
\hline \multirow[t]{3}{*}{$\mathrm{S} / \mathrm{N}$} & \multicolumn{10}{|c|}{ Response } & \multirow{3}{*}{$\begin{array}{l}\text { Arithmetic } \\
\text { mean }\end{array}$} & \multirow{3}{*}{$\begin{array}{l}\text { Standard } \\
\text { deviation }\end{array}$} \\
\hline & \multicolumn{2}{|c|}{$\begin{array}{l}\text { Strongl } \\
\text { y agree }\end{array}$} & \multicolumn{2}{|c|}{ agree } & \multicolumn{2}{|c|}{$\begin{array}{l}\text { Rather } \\
\text { agree }\end{array}$} & \multicolumn{2}{|c|}{ disagree } & \multicolumn{2}{|c|}{$\begin{array}{l}\text { Strongly } \\
\text { disagree }\end{array}$} & & \\
\hline & $\mathrm{T}$ & $\%$ & $\mathrm{~T}$ & $\%$ & $\mathrm{~T}$ & $\%$ & $\mathrm{~T}$ & $\%$ & $\mathrm{~T}$ & $\%$ & & \\
\hline $\mathrm{X} 20$ & 2 & 5,4 & 18 & 33,4 & 8 & 32,6 & 4 & 13,1 & 4 & 12,4 & 2,6543 & 1,9865 \\
\hline $\mathrm{X} 21$ & 1 & 3,4 & 7 & 12,3 & 6 & 56,7 & 23 & 33,7 & 4 & 7,7 & 1,9870 & ,4467 \\
\hline $\mathrm{X} 22$ & 3 & 3,4 & 2 & 1,5 & 6 & 32,3 & 32 & 45,7 & 23 & 32,6 & 4,2345 & ,0986 \\
\hline $\mathrm{X} 23$ & 2 & 2 & 3 & 3,2 & 4 & 21,7 & 43 & 55,4 & 54 & 35,8 & 2,6783 &, 1245 \\
\hline $\mathrm{X} 24$ & 2 & 1 & 4 & 3,1 & 12 & 87,3 & 12 & 34,2 & 12 & 34,4 & 1,4356 &, 7690 \\
\hline $\mathrm{X} 25$ & 4 & 5,3 & 6 & 11,1 & 6 & 32,3 & 67 & 23,2 & 3 & 6,3 & 1,2789 & ,2375 \\
\hline $\mathrm{X} 26$ & 1 & 3,2 & 12 & 21,7 & 12 & 54,6 & 43 & 45,6 & 5 & 23,2 & 4,2356 & 1,2765 \\
\hline $\mathrm{X} 27$ & 2 & 1,1 & 2 & 4,7 & 11 & 12,7 & 23 & 33,0 & 9 & 16,1 & 2,1765 & ,2367 \\
\hline $\mathrm{X} 28$ & 1 & 3,1 & 2 & 5,5 & 14 & 56,7 & 13 & 23,8 & 12 & 20,9 & 36578 &, 8763 \\
\hline indicator & & & & & & & & & & & 4,2356 & ,23467 \\
\hline
\end{tabular}

This paragraph aims at testing the moral correlations between the study's variables at the Jordan Tourism Board depending on the values of the simple correlation coefficient and the moral correlation test among the study's variables.

Table (8) shows the results of the statistical tests which were carried out to determine the correlation between the information technology variables and creative marketing. 


\section{Mll Macrothink}

Table 8. The Correlation Matrix between the Variables of Information Technology and Creative Marketing

\begin{tabular}{|c|c|c|c|c|}
\hline Information technology & $\begin{array}{l}\text { Materialistic } \\
\text { potentials }\end{array}$ & software & $\begin{array}{l}\text { Working } \\
\text { labor }\end{array}$ & Databases \\
\hline \multicolumn{5}{|l|}{ Creative marketing } \\
\hline $\begin{array}{l}\text { Creativity on the level of the international } \\
\text { offices of the board }\end{array}$ & $* *, 653$ & -456 & $* *, 766$ & ,345 \\
\hline $\begin{array}{l}\text { Creativity on the level of tourism activating } \\
\text { center }\end{array}$ & $234, * *$ & 234 & $* *, 234$ &,- 0654 \\
\hline Creativity on the level of the institution & $* * 768$ & 455 & $* *, 234$ & ,345 \\
\hline Organizationalcreativity & $* * 543$ & 234 & $* * 125$ & ,076 \\
\hline
\end{tabular}

Table (8) shows the existence of eleven direct correlations with moral significance out of twenty-six relations and form (55\%) of the total relations, and the presence of three morally insignificant positive correlations which are creativity on the level of the international offices of the board and software dimension and creativity on the level of the institution and database dimension. Table (9) about analysis of variance reveals that the model is moral according to the calculated $F$ value $(12,098)$ which is higher than the spreadsheet value at a moral level of $(0.05)$ and two degrees of freedom $(1,33)$. The explanatory power of this model was $(\mathrm{R} 2=$, $342)$. This refers to the ability of the independent variable to explain $(54 \%)$ of the differences that take place in the dependent variable and that about $(74 \%)$ of the variables were not included in the present model and that they are related to random uncontrollable variables which were not included within the study's variables.

Table 9. Analysis of Variance to the Model of Influence between Software and Creative Marketing

\begin{tabular}{|l|l|l|l|l|l|}
\hline MODEL & Sum of Squares & Df & Mean Square & F & Sig. \\
\hline Regression & 15,654 & 2 & 4.67 & 12,098 &, 000 \\
\hline Residual & 13,89 & 43 &, 654 & - & - \\
\hline Total & 33,435 & 65 & - & - & - \\
\hline
\end{tabular}

$\mathrm{R} 2=0,568$

Based on the aforementioned, we realize the acceptance of the second sub-hypothesis of the 
second main hypothesis which states the existence of moral effect between software and creative marketing.

The results of regression stated in table (10) indicate the model's morality level pursuant to the analysis of variance which showed that the model was moral according to the calculated $\mathrm{F}$ value $(\mathrm{F}=54.467)$ at the morality level $(0.05)$ and two degrees of freedom $(34,1)$. This confirms the acceptance of the third sub-hypothesis of the second main hypothesis which indicates a moral influence relation between working labor and creative marketing.

Table 10. Analysis of Variance to the Model of Influence between Working Labor and Creative Marketing

\begin{tabular}{|l|l|l|l|l|l|}
\hline MODEL & Sum of Squares & Df & $\begin{array}{l}\text { Mean } \\
\text { Square }\end{array}$ & F & Sig. \\
\hline Regression & 43,87 & 5 & 13,765 & 45,21 &, 000 \\
\hline Residual & 23,876 & 45 &, 345 & - & - \\
\hline Total & 23,345 & 67 & - & - & - \\
\hline
\end{tabular}

$$
\mathrm{R} 2=0,346
$$

The coefficient of determination for this variable (working labor) was ( $2=, 349)$ and this value indicates the ability of the independent variable to explain $(87 \%)$ of the differences in the dependent variable and that about $(54 \%)$ of the changes are related to the random uncontrollable variables.

The regression results of table (11) point out the model's morality level according to the analysis of variance which revealed that the model is moral according to $(F=13,567)$ calculated at the morality level $(0.05)$ with two degrees of freedom $(43,1)$.

The coefficient of determination for the variable (databases) was

$(\mathrm{R} 2=, 765)$ and this value indicates the ability of the independent variable to explain $(34 \%)$ of the differences in the dependent variable and that about $(32 \%)$ of changes are related to the random uncontrollable variables. This asserts the acceptance of the fifth sub-hypothesis of the second main hypothesis which states that there is a moral influence relationship between databases and creative marketing. 
Table 11. Analysis of Variance to the Model of Influence between Databases and Creative Marketing

\begin{tabular}{|l|l|l|l|l|l|}
\hline MODEL & Sum of Squares & Df & $\begin{array}{l}\text { Mean } \\
\text { Square }\end{array}$ & F & Sig. \\
\hline Regression & 54,789 & 2 & 4,67 & 23,766 &, 000 \\
\hline Residual & 3,567 & 45 &, 765 & - & - \\
\hline Total & 23,89 & 23 & - & - & - \\
\hline
\end{tabular}

Table 12. Correlation Coefficient for the Most Important Variables

\begin{tabular}{|l|l|l|l|}
\hline MODEL & R & R2 & F \\
\hline Working labor &, 567 &, 678 & 23,9877 \\
\hline Materialistic potentials &, 5467 &, 123 & 65,345 \\
\hline
\end{tabular}

\section{Results}

By analyzing the results of the tests, we find that there is a statistically significant relationship between using modern technological software and creative marketing which contributes in creating a strong competitive advantage for the Jordan tourism board on the international level.

The results affirmed the existence of statistically significant relationship between materialistic potentials and creative marketing as the provision of technological machines and equipment and the effective communication networks contribute in marketing the Jordanian tourist products positively.

The results ascertained the existence of statistically significant relationship between modern technological software and creative marketing, and their diversity contributes in creating a quantum leap in marketing the tourist product reaching the optimal creative marketing and increasing the market share.

The results revealed a statistically significant relationship between the trained qualified working labor and creative marketing.

The results showed a statistically significant relationship between tourist databases and their availability on the website of the tourism board and creative marketing.

When the data is plentiful, accurate and easy to modernize and access in time, this increases the creative marketing and leads to different categories of tourists on the international level. 


\section{Recommendations}

Creating an independent unit within the organizational structure of the Jordan Tourism Board called "Creative Marketing Department" to contribute in preparing innovative marketing policies to market the Jordanian tourist product.

Establishing a joint database between the tourism activating board and all the tourist sector's institutions in order to unify the data and information among those institutions is to place a mutual ground to adopting the concept of creative marketing.

Preparing training programs for all levels of workers at the tourism activating board is to train them on the effective methods of dealing with information technology and modern software in tourism industry.

The tourism activating board should pursue all forms of technological development and modernize the techniques used in the board in addition to training the employees on those techniques to increase creativity and market share.

\section{References}

Ahmed Mohamed Hassan Osman. (2012). Evaluating organizational conflicts between middle-management directors of companies and natural gas distribution and trends of development of management techniques, membership Thesis, Sadat Academy for Management Sciences, Cairo..

Alsarayreh, Jawabreh, Omar, Jaradat,M, \& SA Alamro. (2012). Technological impacts on effectiveness of accounting information systems (AIS) applied by Aqaba tourist hotels. European Journal of Scientific Research, 59(3), 361-369

Ameri, Salih Mahdi Mohsen. (2002). technological innovation: a general framework, the Conference Annual Scientific II, Faculty of Economics and Administrative Sciences, University of Zaytuna, Amman, Unpublished MA Thesis, University of Jordan, Amman, Jordan.

Ahmed Sayed Mustafa. (2010). Managing organizational behavior: a contemporary vision of the behavior of people at work, Cairo.

Ahmed Maher. (2005). Organizational Behavior, University House for Printing and Publishing in Alexandria - Egypt.

Windsor, E. (2008). Turning information into intelligence, Evaluation Centre. DM Review Magazine. (April 2001).

Fuad Najib Sheikh. (June 2013). A culture of innovation in small businesses in Jordan. Arab Journal of Management, 24(1), S47-73. Egypt: Arab Organization for Administrative Development, p. 49.

Fawzi Shaaban Nada. (1991). The impact of environmental, regulatory and behavioral variables on the efficiency of hospital performance (a comparative study with the application on the public hospitals, hospitals General Authority for Health Insurance) $\mathrm{PhD}$ thesis, 
University of Cairo, Faculty of Commerce.

Jawabre, Omar. (2014). The Impact of Customer Relationship Marketing by Aqaba Economic Zone "A Case Study of Five Stars Hotels". International Journal of Academic Research in Accounting, Finance and Management Sciences, 4(1), 167-174. http://dx.doi.org/10.6007/IJARAFMS/v4-i1/583

Hisham Mohammed Sabri. (1994). Different styles to management and its impact on the degree of satisfaction of the employees organizational conflict, unpublished Master Thesis, Faculty of Commerce, Cairo University.

Kefah, Alshawagfih, Omar, Alananzeh, \& Omar, Jawabreh. (2015). THE FOUNDATIONS OF SELECTING CULTURAL TOURISM PRODUCT IN JORDAN. European Scientific Journal, 11, 29

Khaled Youssef Al Zoubi, \& Hussein Mohamed Azab. (2005). measuring working organizational climate trends in the adoption of Creative Behavior: An Empirical Study on the Irbid District Electricity Company, Faculty of Economics and Administrative Sciences, Mutah University.

Kotler, Philip. (2000). Marketing management. The Millennium Edition. prentice - Hall. Inc., New Jersey.

Mamoun Nadim Akroush, \& Suhair Nadim Akroush. (2004). Creativity and innovation management, Jordan: Dar Wael Publishing, 10.

Mohammad ALsarayreh, Omar A. A. Jawabreh, Khalid ALkharabsheh, \& Mohammed Aldahamsheh. (2011). Tourism Promotion through the Internet (Websites) (Jordan as a Case Study). Asian Social Science, 7(6). http://dx.doi.org/10.5539/ass.v7n6p125

Musa Lozi. (1999). Organizational Development: Fundamentals and concepts of modern. The first edition, Dar Wael for printing and publishing, Amman.

Najem Abboud Najem. (2013). Innovation management: concepts and characteristics of modern experiments, Jordan: Dar Wael Publishing, 302-303.

O'Brien James. (2004). Management Information Systems: Managing Information Technology in the Business Enterprise, 6th ed. McGraw-Hill.

Omar A.A. Jawabreh, \& Ali Mahmoud Abdallah Alrabei. (2012). The Impact of Accounting Information System in Planning, Controlling and Decision-Making Processes in Jodhpur Hotels. Asian Journal of Finance \& Accounting, 4(1). http://dx.doi.org/10.5296/ajfa.v4i1.1435

Peppard, J., Ward, J., \& Daniel, E. (2007). Managing the realization of business benefits from IT investments, MIS.

March.Plenty, A. (2008). Quarterly Executive, 6(1). Quality control, Evaluation Centre.

Raad Hassan Sahen. (2000). creativity and innovation management, Syria: Dar Alsafa 
Publishing, 28.

Rayner, N. (2007). Understanding packaged analytic applications, Gartner Inc.

Salim Boutros Jeldeh, \& Zaid Munir Abboy. (2012). creativity and innovation management, Jordan: Dar Kenouz knowledge, 22.

Slack, Nigel, Chambers, Stuart, Christine Harland, \& Alan Robert Johnston. (2004). Operation Management, 4th Ed., London, PITMAN, publishing.

Tai, Mohammed Abdul. (2005). Introduction to Management Information Systems. Dar Wael for Publishing, Amman.

Thabit Abdul Rahman Idris, \& Jamal al-Din Mohammed Mursi. (2012). Organizational behavior - theories and models and practical application of behavior management in the organization, University House, Alexandria, Egypt.

Turban, E., Miclean E., wetherbe, J., westfall, R., \& Raine, K. (1999). Information Technology for management, Making connections for strategic Advantage, 2nd ed, John Wiley,\&sons,NewYork.

Wenger, Albert E. (2000). Three Essays on The Influence of Information Technology on the Organization of Firms. DAL-A 60/01. 